\title{
REAL ESTATE AS A SUBJECT OF SPATIAL CONFLICT AMONG CENTRAL AND LOCAL AUTHORITIES
}

\author{
Alina Źróbek - Różańska, PhD \\ Faculty of Economics \\ University of Warmia and Mazury in Olsztyn \\ e-mail: alina.zrobek@uwm.edu.pl \\ Elżbieta Zysk, PhD \\ Faculty of Geodesy and Land Management \\ University of Warmia and Mazury in Olsztyn \\ e-mail:elzbieta.zysk@uwm.edu.pl
}

\begin{abstract}
Currently, real estate located in rural areas neighboring cities are under pressure to become a location for the realization of urban and metropolitan projects. Thus, spatial conflicts are an inherent characteristic of modern urban development. Such conflicts vary in terms of the scope, intensity and course they take. An interesting case illustrating the given issue can be the conflict over real estate owned by the State Treasury (central authority) and localized within the power of local authorities (gminas). Such a situation requires mediating and producing an outcome that satisfies the goals of both sides. The authors based the deliberations on the topic of spatial conflicts on the example of the relation between the Agricultural Property Agency division in Olsztyn (APA Olsztyn) and the smallest local administration units (gminas) located within the borders of the Warmia-Masuria (Województwo Warmińsko-Mazurskie) and Podlasie (Województwo Podlaskie) Provinces. The aim of the research was to describe the background for potential conflict and to study its proceedings. The aim was achieved through studies of relevant literature and data analysis.
\end{abstract}

Key words: spatial conflict, real estate, land, Agricultural Property Agency, local authorities.

JEL Classification: H82, Q15, R38, R58.

Citation: Źróbek-Różańska A., Zysk E., 2015, Real Estate as a Subject of Spatial Conflict Among Central and Local Authorities, Real Estate Management and Valuation, Vol. 23, No. 2, pp. 88-98.

DOI: $10.1515 /$ remav-2015-0018

\section{Introduction}

Generally, rural areas were traditionally used for agricultural purposes. However, as a result of economic and social evolution, they have progressively shifted from agrarian landscapes to low density areas characterized by an increasing diversity of uses and the constant expansion of building functions (SARACENO 1994). One of the noticeable occurrences in the modern rural areas is the uncontrolled sprawl of cities, referred to as "urban sprawl". Currently, the majority of European and American cities have extended onto nearby agricultural land (COISNON et al. 2014). This occurrence becomes a common urban development problem due to its "leap frog" appearance, which means that localizing singular urban functions as an "island surrounded by a sea of traditionally rural areas", is significantly conflicting. Therefore, various authorities aim to control the transformation of agricultural land by planning and zoning policies. However, the general trend is for the large majority of urbanized land to have been converted from agricultural uses (GREENE and STAGER 2001; WALKER 2001; EEA 2006; LIVANIS et al. 2006). It is also recognized that agricultural amenities in suburban areas 
have a strong pull effect on household location decisions and may encourage the development of areas occupied by both farmers and commuting households (ROE et al. 2004; CAVAILHÈS et al. 2004; READY and ABDALLA 2005). A fundamental problem of "urban sprawl" is its uncontrollability, resulting in spatial order disturbances (ŹRÓBEK-RÓŻAŃSKA et al. 2014). Agricultural land is subjected to pressure for realizing urban and metropolitan projects, which results in spatial conflicts. The term "conflict" relates to the situation occurring among people who represent particular social groups, public governance or inhabitants of particular areas. Spatial conflict arises and develops over different spatial use and its connected external effects. Moreover, the need for the development of urban areas and rural territories in the field of urban influence is accompanied by new conflict situations or the reemergence of "old" ones. These generally result from contradictions between qualitative and quantitative development, and agricultural needs and the needs of other rural area inhabitants (HOPFER et al. 1987).

\section{When conflicts over rural areas arise?}

It can be assumed that, on average, half of the conflicts begin when particular groups of people hope to prevent specific activity. The second half of conflicts arise when somebody wants to stop or reverse the consequences of unwanted land use (i.e. the development of transport infrastructure, waste management, production and transport of energy, etc., in the proximity of a residential area). Such land conversions can lead to the degradation of agricultural land, as land properties are destined for other, non-agricultural purposes, and become an obstacle for the continuation of agricultural use.

Conflict is a social process (MARKOWSKI 1999), thus the participants of conflict are natural persons and persons representing various institutions characterized by different points of view and varying value systems. For example, the following pairs can be involved in spatial conflict:

- local and governmental authorities,

- local authorities and representatives of the opposition,

- local authorities and the local authorities of a neighboring unit (or higher level authorities),

- local authorities and representatives of business organizations.

In the above-mentioned groups, conflicts arise mainly over the central planning of public investments or when opposition's leaders vote against an investment and its impact on the natural environment. Moreover, conflict can emerge in situations when local authorities vote against the development of non-agricultural functions in the neighboring gmina (municipality), or when real estate planning and management in the gmina is contradictory to the interest of a particular person, etc.

M. PACIONE (2013) refers to rural areas near towns and cities as a "battle ground", where a variety of land uses compete for dominance. He describes various conflict participants, i.e.:

- rural producers - essentially landowners who are primarily concerned with the productive capability of their land, the most obvious group being farmers;

- speculators - they may own land that is still in productive use but their basic interest lies in its appreciating value. Their decisions are based on factors such as depreciation rates, capital gain, tax rates and the comparative viability of alternative investment opportunities;

- builder-developers - install basic infrastructure and utilities on the site and construct and sell houses on the prepared lots;

- households - can be either potential house purchasers or existing residents. Both groups are motivated by the same factors, i.e. the functional utility of the house as a place of living and the improvement or at least maintenance of the financial investment represented by their property. However, for existing residents, these considerations may underlie an anti-growth stance;

- real estate agents-purvey information between house buyers and sellers. As their rewards come from commissions charged on each completed property transaction, real estate agents have a vested interest in promoting residential development and land transfers;

- financiers - provide the capital necessary for the development process. Their decisions are based on a combined desire to obtain the highest possible rate of return on loans and minimize or avoid risk;

- pressure groups - can be national organizations pursuing general policies or local community councils and resident associations mobilized in the support of a particular issue;

- government-all governments influence the process of urban development, although the level of involvement varies. The state - central and local government - exercises both a direct (e.g. 
planning regulations) and indirect (e.g. taxation policy) influence on urban form. In the context of power and conflict in the urban fringe, particular importance is attached to the relationship between the central and local government and, specifically, the degree of autonomy of the latter.

However, it should be emphasized that spatial conflicts are different in nature, intensity and proceedings. Some conflicts induce strong emotions, their proceedings are stormy and they are widely commented on in national media ${ }^{1}$, while other conflicts engage only parts directly connected with the issue and are calmly solved through social consultations and negotiations ${ }^{2}$. A specific type of spatial conflict is illustrated by the case of real estate management conducted by local authorities over land received from the Agricultural Property Agency (APA).

In this article, deliberations over spatial conflicts are based on the relation between the Olsztyn APA and authorities of gminas located within Warmia-Masuria and Podlaskie Provinces. The main purpose of the study was to recognize the base for a potential spatial conflict and its possible proceedings. To achieve this aim, adequate literature and scientific journals were reviewed, and data analysis was conducted. Primary data were acquired directly from the APA in Olsztyn. The results were described and supported by figures and tables.

\section{Base for potential conflict}

The participants of spatial conflict can be recognized as central and local authorities. Therefore, the authors studied the relations between the institution representing the interest of central authorities (APA) and local authorities, representing the interests of gminas.

\section{1) Agricultural Property Agency}

The APA, being a legal person and acting as a trustee of the State Treasury of the Republic of Poland, participates in privatization and restructuration processes. The main purpose of the APA's activity is generally creating and improving the structure of family farms. As a result, the APA has an impact on establishing and enlarging agricultural farmlands, and reducing unemployment through creating new workplaces in the Agricultural Property Stock of the Treasury. Moreover, the APA gratuitously transfers land to local units for public purposes, e.g. buildings communal roads (SUCHOŃ 2013).

As the Treasury's trustee, the Agency realizes tasks resulting from the state policy, especially regarding:

- tasks connected with the improvement of farm structures, counteracting the excessive concentration of agricultural property and ensuring the management of agricultural holdings by farmers with appropriate qualifications or experience;

- creating conditions for the rational use of the production potential of Agricultural Property Stock of the Treasury;

- restructuring and privatizing Agricultural Property Stock of the Treasury;

- monitoring economic turnover of real estate and other components of the State Treasury Stock;

- administrating the Treasury Stock destined for agricultural purposes;

- securing the Treasury Stock;

- initiating development works on the Treasury's land and supporting works on private agricultural land;

- exercising ownership rights in plant and animal breeding companies of particular importance for the national economy.

The above result in priorities which imply certain uses of land the rights to which were transferred to the new landowners or land users. Thus, the dominant function of land should be:

- an agricultural function,

- or a function that positively affects the agricultural function,

- or a function neutral to the agricultural function.

\footnotetext{
1 e.g., wind turbines. Residents of houses neighboring planned wind turbines are usually strongly against such projects and express it with strong emotions at meetings with local authorities, or even manifest in the capitol.

2 e.g, commercial investments, such as hotels or malls localized in areas which can alternatively serve as green areas with a public space function. After negotiations, a compromising solution is often worked out.

${ }^{3}$ http:/ / www.anr.gov.pl/web/guest/o-agencji2 (access date: 21.11.2014).
} 
In addition, the APA was equipped with the rights to perform (on behalf of the Treasury) discreet control over the agricultural real estate market and, when necessary, intervene through the right to preemption. As a result of the above, the agency can make decisions connected with the use of and way of transferring rights to real estate ${ }^{4}$.

The scope of the APA's activities depends on current legal regulations describing the operational framework, and the resulting rights and duties. For example, the APA is obliged to manage real estate stock in a rational way, which means management leading to both social and economic effectiveness. Moreover, the agency is obliged to transfer predicted earnings to the state budget. Therefore, the transfer of rights to land or other real estate (usually by tender) should contribute to the realization of particular social aims, and on the other hand - bring incomes ensuring economic effectiveness (excluding exceptions which are justified and predicted in the regulations). Achieving economic efficiency requires selling the rights to the real estate for a maximum market price.

The situation is more complicated when the party acquiring the rights to the real estate is a local administration unit, especially a gmina. This unit can participate in a public tender on the same terms as other natural or legal persons, and buy real estate for the highest offered price. On the other hand, gminas can apply for gratuitous transfer. This form is an important support for many institutions with limited financial resources, especially local authorities. According to the legal regulations, gminas can use gratuitously transferred land for investments important to local societies - to improve living conditions and the quality of life. In such a situation, when financial inflows are impossible, social effectiveness has to be assured; therefore, gratuitously transferred real estate can be used only for the purpose that was mutually agreed on.

\section{2) Local authorities - gminas}

Local authorities should manage communal real estate stock according to the principles of rational management (ŹRÓBEK et al. 2014), thus social and economic effectiveness is required. The general objective connected with public real estate stock management is the realization of public tasks, meaning such that benefit the inhabitants of the area. In the case of a gmina, the realization of tasks should, in practice, contribute to the improvement of living conditions and the quality of life for the gmina's residents, as they are the ones responsible for electing the authorities. Therefore, it can be assumed, that local authorities should mainly respond to the needs of their electors. Improving living conditions and the quality of life can be achieved by various investments, conducted and coordinated by both local authorities as well as private investors. Each investment needs particular space (namely - real estate), to be localized in. Thus, each new investment permanently converts an area, changes its function and character, and produces many external effects (both positive and negative). Consequently, urban and local development requires the use of land which is imperfect and characterized by significantly limited resources (ALEXANDER 2014), owned by natural and legal persons, both private and national (local). Therefore, the need to acquire and develop land and other real estate localized in the borders of the gmina but owned by the State Treasury emerges.

In the current practice of public real estate stock management ${ }^{5}$, the Treasury can transfer rights to real estate for payment or gratuitously. As real estate stock is limited, there is an increasing demand for developing land which was traditionally used for agricultural purposes. This results in urbanization pressure on rural areas located in the neighborhood of towns and cities (with the development of the road infrastructure, the term "neighborhood" becomes even more extended) and accompanying urban sprawl. Rural agricultural areas become more attractive for different functions, i.e. housing, industry or storage. Moreover, where areas within the borders of towns and cities are not available, rural areas are in demand for investments connected with urban development, i.e. the development of road or technical infrastructure. Active and effective authorities who manage real estate stock should search for land for investments necessary for local development. Thus, local authorities apply to the APA for land. They may take part in tenders and, in such way, purchase the desired land. However, this requires engaging significant financial resources. Instead, local authorities can apply for gratuitous transfer. However, the condition for acquiring real estate owned by the State

\footnotetext{
4 Ibidem.

5 The beginnings of which are connected with the Regulation of the President of the Republic of Poland of 22 April 1927 (ŹRÓBEK et al. 2014).
} 
Treasury and managed by the APA is using it for the realization of a public purpose investment ${ }^{6}$. A particular agreed use cannot be replaced by another, which does not fulfill the requirements.

Both the APA and local authorities are responsible for duties and tasks assigned to them. Moreover, they act within the framework of many national and local regulations. It should be emphasized that the activities of both organizations should stimulate social-economic development of the entire country, thus they should take into consideration various guidelines, from the most general EU policy to the most detailed local development strategy. Citing Strategy Europe 2020 - activities of all public institutions should lead to economic growth, which is "smart, sustainable and inclusive $e^{7 "}$. In other words, pressure is put on innovations and the creation of good quality workplaces along with the protection of the natural environment.

In a more detailed elaboration for Poland - National Development Strategy 2020, the following guidelines can be found:

- the state policy towards rural areas must cover both agricultural and non-agricultural rural development (supporting entrepreneurship and non-agricultural activities);

- accelerating development of small and medium entrepreneurship on rural areas will be possible only when investments are coherent with spatial and urban planning, along with respecting the environmental value of rural areas;

- the low level of agricultural specialization, insufficient investments in agricultural production infrastructure, and the fragmented structure of areas result in lower production effectiveness;

- the key task in regional development is the more effective use of the endogenous potential of the biggest towns and cities, and strengthening the connections between metropolises, urban areas and surrounding rural areas and small towns. The propagation of economic growth onto neighboring areas and taking advantage of the relative advantages of big cities, such as new workplaces, economic cooperation or participation in social and cultural infrastructure, are the expected results. A necessary condition for this process is building communication and teleinformation linkages between urban areas with the surrounding environment, as well as economic, service, cultural, etc., connections. These relations should be supported both by state and local administration;

- investment activities should not lead to uncontrolled urban sprawl, which should be controlled by accelerated and improved spatial planning.

The National Spatial Development Plan of 2030 also highlights that Poland requires the restoration and solidification of spatial order: "In Poland, the following symptoms of the lack of spatial order can be observed: maladjustments of use and development to environmental, cultural and landscape values; disturbing spatial value, economically and socially spendthrift suburbanization; low quality of public space; and chaos in the building forms and architecture of urban complexes." In the strategy for the Warmia-Masuria Province, there are records highlighting the need for modernity and structural transformations, which can be synonymous to converting out-of-date spatial functions into more adequate ones, but with consideration to their external effects. At the same time, local authorities promise their electors to create new workplaces and provide them with modern infrastructural facilities.

Thus, the object of conflict can be land, which simultaneously:

- is agricultural land located in rural areas neighboring an urban area;

- possesses adequate characteristics for the continuation of agricultural function (which is coherent with the APA's aim);

- has adequate characteristics for initiating an alternative function, i.e. industrial, residential, trade, storage, etc. (which can be coherent with the local authorities' aims);

- has economic value, thus can be successfully sold in tender for the highest price (which is coherent with the APA's financial aim, but incoherent with local budget limitations);

- has social value for public purpose investments (which is coherent with the expectations of electors, incoherent with APA's economic effectiveness, coherent with local budget limitations as land can be gained without payment, but imposing investment and opportunity costs);

6 According to the Act on Real Estate Management and Act on Spatial Planning and Management (respectively: Dz.U. from 2014, pos. 518 and Dz.U.2003.80.717)

7 Europan 2020. Available online: http://ec.europa.eu/europe2020/europe-2020-in-anutshell/priorities/index_pl.htmdex_pl.htm (access: 24.11.2014). 
- has an optimal use value which changes over time ${ }^{8}$ (which can be incoherent with local authorities' aims).

\section{Relationship between the APA in Olsztyn and local authorities}

Local authorities may be interested in acquiring real estate with the above-described characteristics. This would mean that local authorities actively manage the space they are responsible for, being real managers of subjected units according to the idea of new public management. Effective management includes activities coherent with cost and benefit calculations, therefore conflicts can arise over attractive prices of real estate owned by the State Treasury and managed by the APA. Such conflict can be based on the financial aims of two different organizations - the gmina, represented by local authorities, and the state, represented by the Agricultural Property Agency. In this particular article, the authors focused on the relationship between the APA in Olsztyn and local authorities interested in land managed by the APA.

Table 1

Olsztyn APA activity in the field of real estate distribution in 2001-2013

\begin{tabular}{|c|c|c|c|c|c|c|}
\hline & 2001 & 2002 & 2003 & 2004 & 2005 & 2006 \\
\hline $\begin{array}{l}\text { Number of public tenders } \\
\text { announced }\end{array}$ & 55198 & 61514 & 64985 & 71620 & 78710 & 86118 \\
\hline $\begin{array}{l}\text { Number of public } \\
\text { tenders held }\end{array}$ & 49996 & 56335 & 59585 & 65552 & 70886 & 77167 \\
\hline Total area of land offered & 1890650 & 1982268 & 2036723 & 2114899 & 2151744 & 2190378 \\
\hline for sale & 364024 & 427329 & 444586 & 493049 & 515909 & 545756 \\
\hline percent & $19 \%$ & $22 \%$ & $22 \%$ & $23 \%$ & $24 \%$ & $25 \%$ \\
\hline for lease & 1526626 & 1554939 & 1592137 & 1621850 & 1635835 & 1644622 \\
\hline $\begin{array}{l}\text { Total permanent } \\
\text { distribution (ha), } \\
\text { including: }\end{array}$ & 274821 & 316551 & 348036 & 374182 & 402623 & 434660 \\
\hline - total sale & 225382 & 263223 & 293476 & 316993 & 343735 & 369776 \\
\hline percent & $82 \%$ & $83 \%$ & $84 \%$ & $85 \%$ & $85 \%$ & $85 \%$ \\
\hline $\begin{array}{l}\text { - gratuitous transfer, } \\
\text { including: }\end{array}$ & 42100 & 44729 & 46219 & 48253 & 49887 & 52039 \\
\hline percent & $15 \%$ & $14 \%$ & $13 \%$ & $13 \%$ & $12 \%$ & $12 \%$ \\
\hline - gminas and other units: & 3106 & 3445 & 3603 & 3720 & 3916 & 4163 \\
\hline percent & $1 \%$ & $1 \%$ & $1 \%$ & $1 \%$ & $1 \%$ & $1 \%$ \\
\hline $\begin{array}{l}\text { Gratuitous transfer to } \\
\text { local units (art. } 60 \text { Act on } \\
\text { Public Administration } \\
\text { Reform ) }\end{array}$ & 3423 & 4010 & 4009 & 4009 & 4013 & 4013 \\
\hline $\begin{array}{l}\text { Average sale prices of } \\
\text { agricultural land (zloty) }\end{array}$ & 3007 & 2834 & 2970 & 4288 & 5001 & 7309 \\
\hline $\begin{array}{l}\text { Number of apartments } \\
\text { transferred gratuitously } \\
\text { to gminas and other units }\end{array}$ & 816 & 997 & 1068 & 1119 & 1303 & 1567 \\
\hline
\end{tabular}

Source: Own elaboration based on data from the APA in Olsztyn.

\footnotetext{
8 Transferring the rights to real estate from the APA to a gmina requires fulfilling many legal regulations, which results in a long term of realization; during this time, the real estate's optimal function and value can change, but regulations prevent introducing quick adjustments.
} 
Table 1 cont.

\begin{tabular}{|c|c|c|c|c|c|c|}
\hline 2007 & 2008 & 2009 & 2010 & 2011 & 2012 & 2013 \\
\hline 90953 & 94784 & 101400 & 108981 & 117275 & 123693 & 129020 \\
\hline 82056 & 85762 & 92053 & 99552 & 108138 & 114106 & 119560 \\
\hline 2213867 & 2229433 & 2253886 & 2283125 & 2314091 & 2338473 & 2361714 \\
\hline 563315 & 575022 & 596958 & 624900 & 654083 & 676295 & 694830 \\
\hline $25 \%$ & $26 \%$ & $26 \%$ & $27 \%$ & $28 \%$ & $29 \%$ & $29 \%$ \\
\hline 1650552 & 1654411 & 656928 & 1658225 & 1660008 & 1662178 & 1666884 \\
\hline 499966 & 538513 & 591181 & 623807 & 656583 & 686890 & 720835 \\
\hline 394242 & 412894 & 436898 & 458596 & 481835 & 504281 & 532713 \\
\hline $79 \%$ & $77 \%$ & $74 \%$ & $74 \%$ & $73 \%$ & $73 \%$ & $74 \%$ \\
\hline 91688 & 111556 & $154273^{9}$ & 165211 & 174748 & 182609 & 188122 \\
\hline $18 \%$ & $21 \%$ & $26 \%$ & $26 \%$ & $27 \%$ & $27 \%$ & $26 \%$ \\
\hline 4333 & 4434 & no data 10 & n.d. & n.d. & n.d. & n.d. \\
\hline $1 \%$ & $1 \%$ & n.d. & n.d. & n.d. & n.d. & n.d. \\
\hline 4013 & 4013 & - & - & - & - & - \\
\hline 10908 & 12075 & 12912 & 13752 & 14378 & 15570 & 17095 \\
\hline 1664 & 1740 & 1770 & 1903 & 1955 & 2049 & 2207 \\
\hline
\end{tabular}

Source: Own elaboration based on data from the APA in Olsztyn.

The activity of the APA in Olsztyn in the field of real estate distribution in 2001-2013 has been presented in Table 1. The number of announced public tenders is shown to increase from year to year - in 2013 the number was doubled in comparison to 2001. Each year, over $90 \%$ of announced public tenders were actually held. Among offered land, the share of land destined for sale revealed an increasing tendency (from 19\% in 2001 to $29 \%$ in 2013). Of the permanently distributed land, the majority was sold (annually over $70 \%$ ), with a significantly smaller portion transferred gratuitously (from $12 \%$ to $21 \%)^{11}$, including about $1 \%$ transferred to gminas and other local administration units. This can be explained mainly by the economic purpose of APA's functioning, especially with the continuously increasing average prices of agricultural land (Fig. 1).

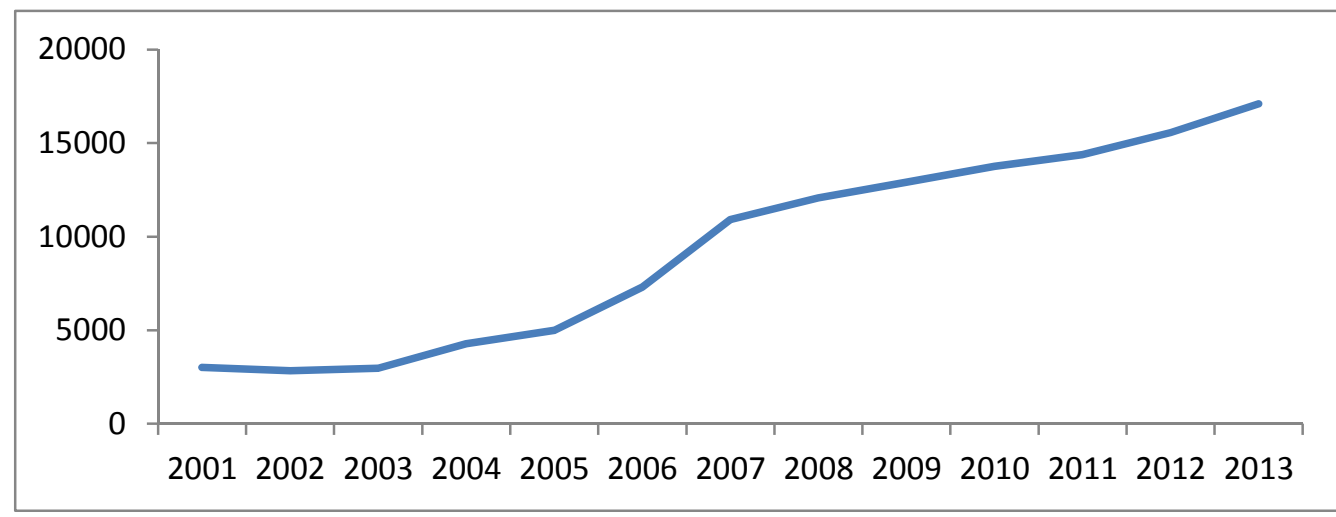

Fig. 1. Average agricultural land prices (in zloty) in 2001-2013. Source: Own elaboration based on data from the APA in Olsztyn.

Simultaneously, an increase in the number of apartments gratuitously transferred to gminas and other local administration units can be observed. Such activity supports achieving social goals.

\footnotetext{
${ }^{9}$ In bold - other than sale payable permanent distribution.

${ }^{10}$ As the method of gathering data changed, data cannot be directly compared. See Fig. 2.

11 Data aggregation method was changed in 2009.
} 
Increasing urbanization pressure, the possibility of applying for direct payments, increasing land value and many other factors encourage the purchase of agricultural land through public tenders. Thus, gminas can buy the desired land only by offering the highest price in a public tender. This is not a popular way of acquiring land, as studies conducted in 2014 show that gminas rarely spend money on purchasing land for real estate stock ${ }^{12}$. Since 1993 (that is for a period of 21 years), the APA and gminas concluded only 11 transactions (Fig. 2). Transactions included a total of 41.2 hectares, and $91 \%$ concerned land sales (only 1 transaction concerned developed land with a building).

Gminas definitely applied for gratuitous transfer for realization of public purpose investments more willingly. Since 1991, the APA in Olsztyn has transferred 3,600 hectares (in comparison to 41.2 hectares sold through public tender) (Fig.3.).

Interviews with workers of the APA in Olsztyn allow to draw a conclusion that the abovementioned situation results from limitations in the budgets of gminas - local authorities do not possess finances that could be allocated in real estate bought by means of public tender. Therefore, local authorities apply for gratuitous transfer much more willingly. Newly acquired land generates costs connected with its maintenance and development, but the highest expenditure - price similar to that of the market price (the purpose of holding a public tender) is omitted. However, achieving land through gratuitous transfer means developing and using the land only for the realization of public investment purposes.

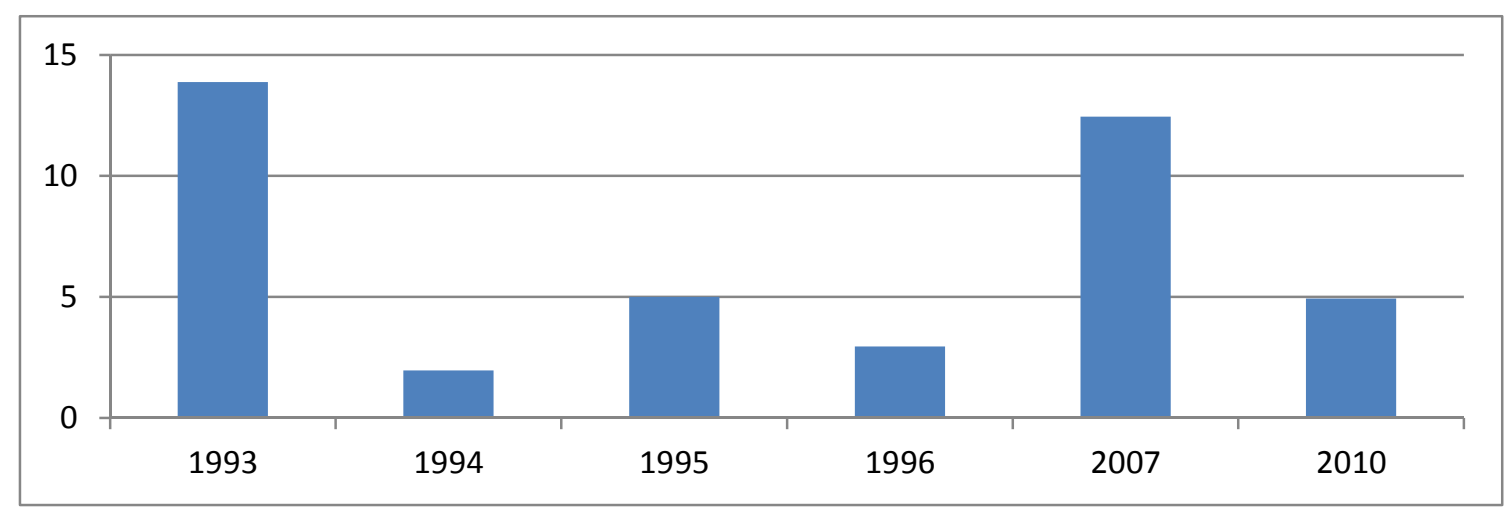

Fig. 2. Area of land (in hectares) sold to gminas through public tender, $1993-2014^{13}$. Source: Own elaboration based on data from the APA in Olsztyn.

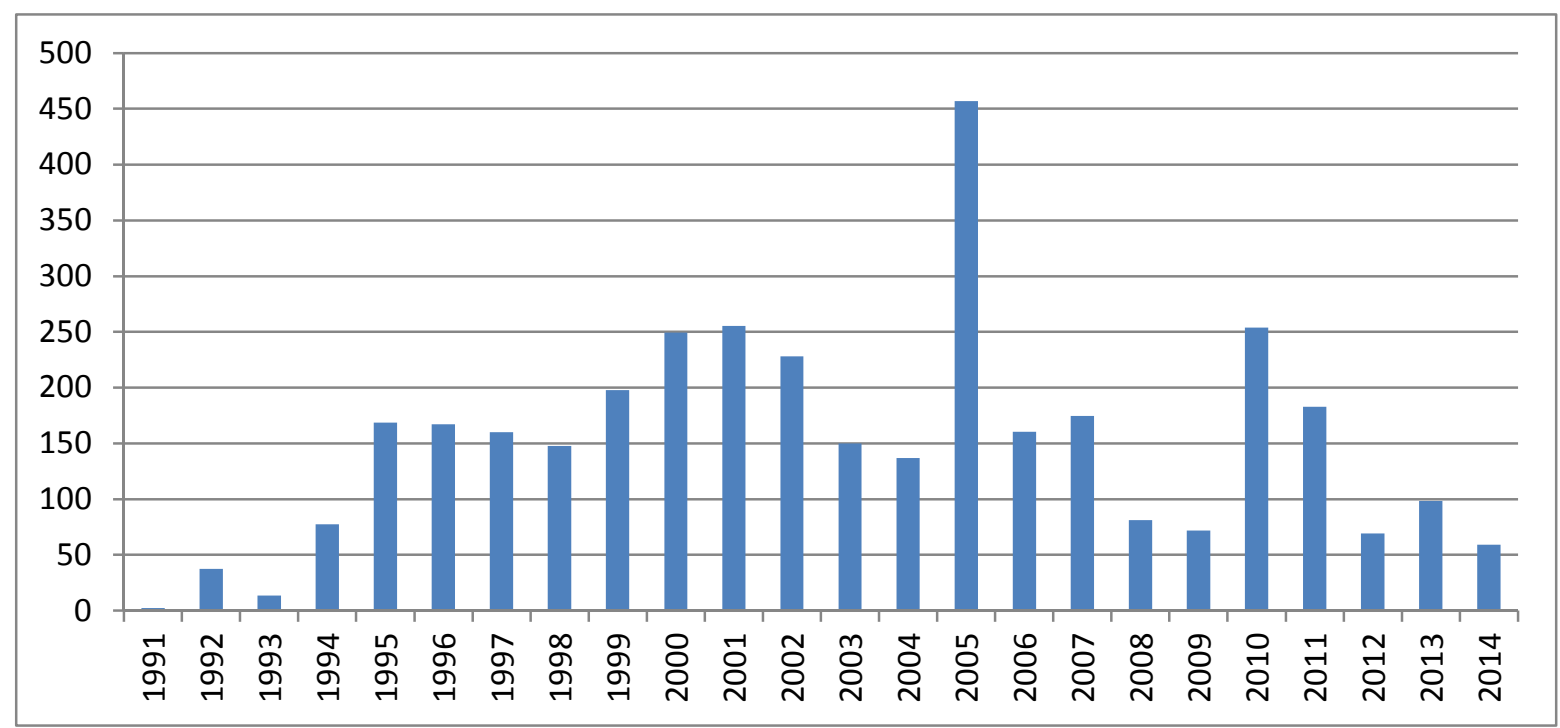

Fig. 3. Area of land (in hectares) transferred gratuitously to gminas by the APA in Olsztyn, 1991 2014. Source: Own elaboration based on data from the APA in Olsztyn.

12 Which confirms the authors' own studies. More in: Źróbek et al. 2014, pp. 328-330.

13 Up to 2014, the last transaction was concluded in 2010. 
Although the area of land transferred gratuitously to gminas and other local administration units by the APA in Olsztyn constitutes only $1 \%$ of permanently distributed land, such transfers take place regularly. When looking at land transferred only to gminas, it can be noticed that the trend is variable. The smallest area was noted in 1991 - about 2 hectares, with the largest in 2005 - over 450 hectares (Fig. 3). By knowing the average agricultural land market prices in the particular years (Tab. 1), demonstrative (excluding differences resulting from localization or fertility) average financial opportunity cost can be assessed; in 2005, this amounted to over 2 million zloty. Such an amount would have been earned if land had been sold instead of being transferred gratuitously. In these cases, the APA, which does not achieve economic effectiveness, is obliged to monitor if the transferred land contributes to social effectiveness. Such a situation can result in spatial conflict, because:

- the APA should enable achieving maximum social effectiveness, in another words, monitor whether or not the real estate is used properly and for the purpose it was transferred. The list of public purposes includes, e.g. solving housing problems in the gmina, or supporting the development of communication, technical and recreational infrastructure that serves residents.

- Authorities of the gmina, when needs and/or financial resources have changed would prefer to use the acquired real estate for purposes other than those agreed on with the APA.

If local authorities use real estate for purposes other than those agreed upon, the APA is obliged to take back the real estate in court. Up to 2014, the APA in Olsztyn recorded three cases when land transferred gratuitously to gminas was taken back by way of legal proceedings. The land had been transferred to build a playground and for infrastructural investments, and taken back because of the lack of development. Another three cases were in process (the same reason), and a fourth case was referred to the court. Up to the end of 2014, only one case was solved by reaching a compromise both sides agreed on changing the purpose: building a sewage pumping station was replaced with recreational functions.

\section{Conclusions}

Currently, urban development needs extend significantly beyond the administrative borders of urban areas, and the tendency to convert agricultural land to land favoring urban needs has been continuously increasing. Urban development requires the conversion of agricultural land to other functions, i.e. housing. However, land as a resource is significantly limited, thus competition among alternative functions becomes even stronger, which consequently leads to spatial conflicts. The descriptions of spatial conflicts and characterization of its participants can be found in relevant literature. Spatial conflict can be illustrated by the relation between state level authorities (or institutions acting on behalf the state) and local authorities. Studies conducted in this article focused on the relation between the Olsztyn division of the Agricultural Property Agency (APA Olsztyn) and local authorities (gminas).

Local authorities can acquire real estate owned by the State Treasury and managed by the APA in one of two ways: by winning the public tender or applying for gratuitous transfer for public purpose investments. In practice, the APA in Olsztyn has concluded only 11 sales transactions with local authorities since 1993, with the majority of real estate transferred gratuitously. Therefore, in these cases the APA did not obtain incomes from the sale of property and had to monitor if the transferred land contributed to social effectiveness. Such situations led to spatial conflicts in a few of the cases: in eight gminas, public purpose investments were not realized or local authorities tried to use the land for a function different than that which had been agreed on with the APA. Therefore, the APA in Olsztyn was obliged to initiate legal proceedings to take back the transferred real estate in court. There was only one case when the conflict was successfully solved and a compromise was worked out land function was changed in the agreement. Up until 2014, such conflict situations were quite rare; however, it can be expected, that in the future they will arise more frequently as real estate stock is very limited and real estate value increases over time. This is caused, i.e. by changes in the environment surrounding real estate managed by the APA - along with spatial urban development, agricultural land becomes localized in the neighborhood of the city (in the so-called suburban zone) and, therefore, in the proximity of urban infrastructure. Thus, e.g. due to its production potential, the value of agricultural property increases when the access road is of good quality (FORYŚ, PUTEK-SZELĄG 2013), as the road investment contributes to the increased differentiation of transaction prices - areas considered attractive before, located close to urban areas, were distinguished by even higher prices after the commencement of road construction (RADZISZEWSKA, JAROSZEWICZ 2013). Moreover, as the 
result of urban sprawl, an increase in real estate value can be observed even in more distant areas, such as on the borders of a poviat ${ }^{14}$ (TANAŚ 2014). Consequently, one of the priorities in areas subjected to the pressure of urbanization is to satisfy the local community's demand for a technical and social infrastructure. Public purpose investment projects are therefore essential (WoLNY et al. 2014). For that reason, the APA in Olsztyn and local authorities should elaborate the strategy for cooperation in order to find compromising solutions instead of legal proceedings in court.

\section{References}

AgENCJA NiERUCHOMOŚCI ROLNYCH (Agricultural Property Agency). http:/ / www.anr.gov.pl/web/guest/o-agencji2 (access date: 21.11.2014)

ALEXANDER E.R., 2014, Land-property markets and planning: a special case, Land Use Policy, No. 41.

CAVAILHÈS J., PEETERS D., SÉKERIS E., THISSE J.F., 2004, The periurban city: why to live between the suburbs and the countryside, Regional Science and Urban Economics, No. 34(6), pp. 681-703.

CHRISTENSEN F.K., 2014, Understanding value changes in the urban development process and the impact of municipal planning, Land Use Policy, No. 36, pp. 113-121.

COISNON T., OUESLATI W., SALANIÉ J., 2014, Urban sprawl occurrence under spatially varying agricultural amenities, Regional Science and Urban Economics , No. 44, pp. 38-49.

EUROPEAN ENVIRONMENT AGENCY, 2006, Urban sprawl in Europe, the ignored challenge. Report. European Commission.

FORYŚ I., PUTEK-SZELĄG E., 2013, Structure stability of agricultural lands of the real estate sold by the APA (Agencja Nieruchomości Rolnych) in Szczecin, Real Estate Management and Valuation, Vol. 21, No. 2, pp. 45-55.

GREENE R.P., STAGER J., 2001, Rangeland to cropland conversions as replacement land for prime farmland lost to urban development, The Social Science Journal, No. 38 (4), pp. 543-555.

HOPFER A., ŹRÓBEK S., ŹRÓBEK R., 1987, Planistyczne i urządzenioworolne aspekty rozwoju miast. Wydawnictwo ART., Olsztyn, p. 143 and next.

JaroszeWICZ J., RADZISZEWSKA W., 2013, Analysis of Changes in Prices of Land in the Vicinity of National Roads, Real Estate Management and Valuation, Vol. 21, No. 1, pp. 77-87.

Livanis G., Moss CH.B., Breneman V. E., Nehring R. F., 2006, Urban sprawl and farmland prices, American Journal of Agricultural Economics, No. 88 (4), pp. 915-929.

MARKOWSKI T., 1999, Zarządzanie rozwojem miast, PWN, Warszawa.

PACIONE M., 2013, Private profit, public interest and land use planning - A conflict interpretation of residential development pressure in Glasgow's rural-urban fringe, Land Use Policy, No. 32, pp. 61-77.

READY R. C., ABDAlla CH.W., 2005, The amenity and disamenity impacts of agriculture: estimates from a hedonic pricing model, American Journal of Agricultural Economics, No. 87 (2), pp. 314-326.

ROE B., IRWIN E.G., MORROW-JONES H.A., 2004, The effects of farmland preservation, and other neighborhood amenities on housing values and residential growth, Land Economics, No. 80 (1), pp. 55-75.

SARACENO E., 1994, Recent trend in rural development and their conceptualization, Journal of Rural Studies, No. 10 (4), pp. 321-330.

SuCHOŃ A., 2013, Ramy prawne funkcjonowania Agencji Nieruchomości Rolnych a rozwój obszarów wiejskich i unowocześnianie rolnictwa, [in:] Rola Agencji Nieruchomości Rolnych w unowocześnianiu rolnictwa $i$ obszarów wiejskich. Red. R. Marks-Bielska and R. Kisiel, Wyd. UWM w Olsztynie, p. 25 and next.

TANAŚ J., 2014, The origin of the buyers of properties in Poznan and its suburbs, Real Estate Management and Valuation, Vol. 22, No. 2, pp. 5-12.

WALKER R., 2001, Urban sprawl and natural areas encroachment: linking land cover change and economic development in the Florida Everglades, Ecological Economics, No. 37 (3), pp. 357-369.

WOLNY A., ŹRÓBEK - RÓŻAŃSKA A., ŹRÓBEK R., PIOTROWSKI M., FREY J., 2014, Development of areas and public purpose investments in the suburban territory, Real Estate Management and Valuation, Vol. 22, No. 2, pp. 86-97.

ZARZĄD WOJEWÓDZTWA WARMIŃSKO-MAZURSKIEGO. Strategia rozwoju społeczno-gospodarczego województwa warmińsko-mazurskiego do roku 2025 (Social-economic development strategy for Warmia and

\footnotetext{
${ }_{14}$ Administrative unit larger than a gmina (next level).
} 
Mazury) Access online: http://strategia2025.warmia.mazury.pl/artykuly/72/strategia-2025.html\# (access date: 24.11.2014).

ŹRÓBEK-RÓŻAŃSKA A., ŹRÓBEK S., ŹRÓBEK R., 2014, Urban Sprawl and the Problems of Changes of Land Use on the Fringe Areas of Towns, Enviro Selected Papers 2014. Available online: http:/ / enviro.vgtu.lt

ŹróbeK R., ŹRóBeK S., ŹRÓBEK-RÓŻAŃSKA A., ŹRÓBEK-SOKOLNIK A., DYNOWSKI P., 2014, Podstawy $i$ procedury gospodarowania publicznymi zasobami nieruchomości. Wyd. UWM w Olsztynie, pp. 9 onwards. 